\title{
Het neuron als bruggenbouwer
}

Citation for published version (APA):

Steinbusch, H. W. M. (1999). Het neuron als bruggenbouwer: bridging disciplines by neurons. Instituut hersenen en gedrag. https://doi.org/10.26481/spe.19990305hs

Document status and date:

Published: 05/03/1999

DOI:

10.26481/spe.19990305hs

Document Version:

Publisher's PDF, also known as Version of record

\section{Please check the document version of this publication:}

- A submitted manuscript is the version of the article upon submission and before peer-review. There can be important differences between the submitted version and the official published version of record.

People interested in the research are advised to contact the author for the final version of the publication, or visit the DOI to the publisher's website.

- The final author version and the galley proof are versions of the publication after peer review.

- The final published version features the final layout of the paper including the volume, issue and page numbers.

Link to publication

\footnotetext{
General rights rights.

- You may freely distribute the URL identifying the publication in the public portal. please follow below link for the End User Agreement:

www.umlib.nl/taverne-license

Take down policy

If you believe that this document breaches copyright please contact us at:

repository@maastrichtuniversity.nl

providing details and we will investigate your claim.
}

Copyright and moral rights for the publications made accessible in the public portal are retained by the authors and/or other copyright owners and it is a condition of accessing publications that users recognise and abide by the legal requirements associated with these

- Users may download and print one copy of any publication from the public portal for the purpose of private study or research.

- You may not further distribute the material or use it for any profit-making activity or commercial gain

If the publication is distributed under the terms of Article $25 \mathrm{fa}$ of the Dutch Copyright Act, indicated by the "Taverne" license above, 


\title{
HET NEURON
}

\author{
ALS
}

BRUGGENBOUWER

"Bridging disciplines by neurons"

H.W.M. Steinbusch

5 maart 1999 

Rede

in verkorte vorm uitgesproken bij de aanvaarding van het ambt van profileringshoogleraar in de "Cellulaire Neurowetenschappen" aan de Universiteit van Maastricht op vrijdag 5 maart 1999

door

Prof.Dr. H. (Harry) W.M. Steinbusch

Universiteit Maastriclit

Instituut Hersenen en Gedrag 
Instituut Hersenen en Gedrag

Universinteit Mastricht

Fucultet der Genceskunde

Postbus 616

$6200 \mathrm{MD}$ Malastrichl

tel: $043-3881021$

fax: $043-3671096$

e-mail:HA Steinbusch@op unimaas. wi

Illugtratie: Marcel Dijkstra

Vormgeving en drukwerk: Unigraphic, Universiteit Maastricht 


\section{HET NEURON ALS BRUGGENBOUWER "Bridging disciplines by neurons"}

Mijnheer de Rector Magnificus,

Leden van het Bestuur van de Universiteit,

Leden van het Bestuur van de Stichting Wetenschapsbeoefening Universiteit Maastricht,

Leden van het Bestuur van de Faculteit der Geneeskunde,

Leden van het Bestuur van het Onderzoeksinstituut Hersenen en Gedrag,

Zeer geachte dames en heren,

Aan het eind van deze winter beginnen velen van ons met reisplannen te maken voor de komende zomer. We hebben tegenwoordig de mogelijkheid om naar liedere hoek van de aardbol te reizen en steeds grotere afstanden te overbruggen. Onze aarde vertoont geen onontdekte, witte vlekken meer. We raken gewend aan de gedachte, dat de komende generaties steeds dieper in de Kosmos zullen doordringen. Intussen zijn we vertrouwd geraakt met planeten en sterrenstelsels die ver weg zijn gelegen, dankzij een Hubble telescoop of Starwars en zelfs Startrek, zie bijvoorbeeld dit melkwegstelsel Carthweel.

Echter, het misschien wel belangrijkste, nog grotendeels onontdekte territorium ligt in ons zelf, de Mikro-Kosmos van ons Brein. Een zekere ironie ligt in het feit dat onze hersenen op zichzelf oneindig dichtbij zijn gelegen, maar wél het vijwel onbeperkte vermogen hebben om oneindig verre werelden te creeren, enkei en 
alleen door het observeren en analyseren van de concrete, eindige wereld om ons heen. Van de andere kant is ons Brein een tastbaar object van beperkte omvang dat slechts indirect door een naar buiten gericht sensorisch orgaam, de ogen, voor andere levende wezens herkenbaar is. We herkennen het slechts indirect, het is verstopt of verpakt in het hoofd van anderen, in een gesloten container wan botweefsel, met enige openingen aan de onderkant richting de wervelkolom. Het wordt door huid en haren omluuld en het onttrekt zich aan ons directe zicht. Toch is dit het centrum, dat wij beschouwen als de "boordcomputer van onze innerlijke existentie, en waar wij ons $\mathbb{K}$ en ons menszijn aan toeschrijven.

Daarom wilde ik u vanmiddag meenemen op een reis naar uw eigen brein. Een brein dat overigens al vanaf uw twintigste levensjaar begint af te sterven. Ontwikkeling en veroudering gaan steeds samen. Voor velen van $\mathrm{U}$ zijn begrippen als vergrijzing van de samenleving niet nieuw. Al snel wordt daarbij gedacht aan ziektes van het ouder wordende zenuwstelsel: de zogenaande neurodegeneratieve aandoeningen. Iedereen heeft in dit verband wel eens van de ziekte van Parkinson en de ziekte van Alzheimer gehoord. Ook het optreden van Depressie kan een teken zijn van een ongunstig verlopend verouderingsproces in de hersenen. In toenemende mate realiseren we ons dan ook, dat depressies een vroeg voorteken kunnen zijn van neurodegeneratieve ziektes. Deze ziektebeelden zullen niet alleen een steeds grotere belasting vormen voor de individuele, ouderwordende mens, maar ook woor de vergrijzende samenlleving als geheel. Daamaast komen door de steeds beter wordende gezondheidszorg in toenemende mate ontwikkelingsaandoeningen onder onze aandacht, zoats schizofrenie en autisme. Zowel de ouderdoms- als de ontwikkelingsgeassocieerde hersenaandoeningen hebben niet alleen gevolgen voor het welzijn van de bevolking, omdat steeds meer mensen er hun nabije omgeving tmee te 
maken zullen krijgen, tevens zal door deze bevolkingsgroep in toenemende mate aanspraak op de gezondheidszorg gemaakt moeten worden.

Voor de belangstellende leek zou ik het motto van de leerstoel "Cellulaire Neurowetenschappen" het beste kumnen omsclurijven als: "de ontwikkeling en teloorgang van hersencellen". Om die beide processen beter te kunnen begrijpen, moeten we, veel meer dan nu het geval is, nieuwe kennis zien te vergaren over hoe de liersencellen hun functie uitoefenen. Daarbij staan de zenuwcellen, ook neuronen genoemd centraal. Op de vak-inhoudelijke aspecten kom ik later nog terug.

Neuronen beschouw ik in meerdere opzichten als bruggenbouwers: zij stellen ons brein in staat te reageren op prikkels van buitenaf en van binnen in ons lichaam. Die prikkels kunnen de hersenen bereiken via de ogen, via geur, smaak, tastzin, temperatuur en ga zo maar door. Andere neuronen zorgen ervoor, dat al deze gegevens verwerkt worden. En weer andere neuronen zijn er verantwoordelijk voor, dat een gecontroleerde en juiste reactie op de prikkels kan optreden.

Als er in de neuronen iets fout gaat met het registreren of verwerken van de gegevens, b.v. omdat een neuron sneller dan de bedoeling was afsterft, dan kan men zich goed voorstellen, dat op menige plaats in de hersenen bruggen beschadigd kunnen worden. En dat er afhankelijk van de plaats, waar dat in de hersenen gebeurt, vele verschillende vormen van "verkeersproblemen", -en dus van ziektebeelden-, kumen ontstaan.

Ook in een ander belangrijk opzicht zijn neuronen te beschouwen als bruggenbouwers: on de ontwikkeling en teloorgang van de hersencellen goed te kumen begripen, is het noodzakelijk om informatie vanut vele vak-richtingen te verzamelen en op elkar af te stemmen. Om op internationat top-wivean 
neurocellulair onderzoek te kunnen doen, is het gewoonweg een "must" dat er bruggen geslagen worden tussen disciplines als neuroanatomie, neurochemie, farmacologie, moleculaire (cel)biologie, neurologie, psychiatrie en neuropsychologie. Alleen op deze wijze kan een zo compleet mogelijk beeld verkregen worden van hetgeen er zich afspeelt van molecule tot patiènt en andersom.

Neurodegeneratieve aandoeningen, zoals de ziekte van Alzheimer en Parkinson, ontstaan waarschijnlijk door een langzame degeneratie en celsterfte in hersenstructuren. De symptomen worden pas zichtbaar, als er een kritische ondergrens in het aantal cellen is bereikt, terwijl de degeneratieve processen dan geruime tijd aan de gang zijn. Volwassen neuronen kunnen zich niet meer delen, dus er kan geen nieuw weefsel aangemaakt worden om de schade te herstellen. Dit betekent, dat op het moment van de constatering van de aandoening er al een onomkeerbare situatie is bereikt. Wanneer de mogelijkheid zou bestaan om veel eerder dan nu het geval is vast te stellen dat zich een neurodegeneratief ziektebeeld aan het ontwikkelen is, zou dat therapeutisch gezuen grote mogelijkheden kunnen bieden. Er kan dan getracht worden ${ }_{s}$ uitgaande van de reedls beschikbare fundamentele, cellulaire neurowetenschappelijke kennis, omtrent celdood en neurodegeneratie, om in te grijpen in het ziekteproces. De kansen om het ziekteproces te vertragen of zelfs te genezen zouden aanzienlijk worden vergroot. Hierdoor zou uiteindelijk voor de oudere mens de kwaliteit van leven ook bij hoge ouderdom sterk kunnen verbeteren.

Op dit moment zijn de oorzaken wan de neurodegeneratieve aandoeningen nog niet exact aan te wijzen. Een gangbare hypothese is, dat er meerdere factoren zijn die leiden tot een gemeenschappelijke destructief mechanisme: oxidatieve stress. 
Oxidatieve stress betekent een negatieve balans tussen het ontstaan van schadelijke radicalen aan de ene kant met aan de andere kant de defensie mechanismen die hiertegen kumen optreden.

Radicalen zijn moleculen, die van nature ontstaan bij de verwerking van zuurstof. Zonder zuurstof kumnen we niet leven, dus radicalen zijn onlosmakelijk verbonden aan dat leven. Radicalen spelen een roll bij de vorming van stoffen, die o.a. belangrijk zijn voor de regeling van de bloeddruk en bij de afweer tegen schadelijke bacteriên. Om deze agressieve radicalen onder controle te houden, beschikken we over zgn. anti-oxidatieve systemen. Wanneer het anti-oxidatiove systeem zijn taken niet naar behoren kan uitvoeren (b.v. door roken, slechte voeding, bij het vorderen van de leeftijd), krijgen de radicalen méér gelegenheid om beschadigingen aan te brengen aan b.v. celmembranen of het DNA. Daardoor kunnen cellen sneller afsterven en kunnen hele groepen cellen (weefsels) hun functie verliezen. Eén van de gevolgen hiervan kan een versneld verouderingsproces zijn.

Ik beschouw het daarom van groot belang om onderzoek te doen naar het zo vroeg mogelijk opsporen van dit soort beschadigingen en zodoende de vroegdiagnostiek te bevorderen. Daarbij acht ik het uitermate zinvol hiervoor ook diemodellen te ontwikkelen. Er wordt dus getracht vroege markers voor neurodegeneratie aan te tonen en deze te valideren in serum, urine, liquor voordat er sprake is van klinische verschijnselen. Vroegtijdig ingrijpen heeft in potentie de mogelijkheid tot herstel. Het diermodel biedt de mogelijkheid on zowel in hersenweefsel als ook in serum te onderzoeken of er een relatie is tussen neuronale schade en biomarkers. 
Inbedding in Instituut Hersenen \& Gedrag en

vakgroep Psychiatríe \& Neuropsychologie

Het wetenschappelijk onderzoek aan de Faculteit der Geneeskunde wordt uitgevoerd binnen een aantal centrale thema's die door de Faculteitsraad in het kader van een meerjarenprogramma voor het wetenschappelijk onderzoek zijn vastgesteld. Binnen dit meerjarenprogramma vigeren aan de UM een zestal thema's, te weten: Hart- \& Vaatziekten, Voeding \& Milieu, Experimentele Psychopathologie, Hersenen \& Gedrag, Extramurale \& Transmurale Gezondheidszorg en Groei \& Ontwikkeling, met daarnaast de aandachtsgebieden "Biomaterialen" en "Onderzoek ten behoeve van Onderwijs".

Het Instituut Hersenen en Gedrag bestaat uit 3 programma's:

- Programma 1: Hersenen \& Cognitie o.l.v. Prof.dr. J. Jolles

- Programma 2: Gedrags- en Belevingsstoornissen o.l.v. Dr. J. van Os

- Programma 3: Mechanismen van Neurodegeneratie en Plasticiteit i.h.b. in relatie tot dierexperimentele modellen voor ontwikkeling en veroudering van het CZS m.b.t. cognitie en affectieve stoornissen o.l.v. Prof.Dr. H.W.M. Steinbusch

In de nieuwe Instituut-structuur is plaats ingeruimd voor een eigenstandig biomedisch onderzoeksprogramma van neurowetenschappelijke signatuur, hetgeen het belang weergeeft van fundamenteel onderzoek binnen de Vakgroep en het Instituut. Als zodanig heeft dit programma zich ook binnen de vakgroep een eigen plaats verworven naast het humane cognitief neurowetenschappelijk onderzoek en het psychopathologisch onderzoek. Het vakgebied is binnen de UM 
nog niet vertegenwoordigd. De Neuropsychologie en de Cellullaire Neurowetenschappen zijn twee wetenschapsgebieden die zich in directe onderlinge samenhang richten op de bestudering van het menselijk gedrag in relatie tot structuur en functie van de hersenen. Het begrip veroudering wordt daarbij niet opgevat als zijnde identick met de problematiek van de geriatrie, het gaat veeleer om de fundamentele processen van veroudering die reeds een aanvang nemen bij de geboorte.

Samenwerkingsrelaties:

Er bestaan binnen de Faculteit der Geneeskunde en het Academisch ziekenhuis Maastricht goede contacten met andere vakgroepen zowel binnen als buiten het Instituut Hersenen \& Gedrag. Als voorbeelden kunnen worden genoemd de vakgroepen Neonatologie, de Neurologie (op het gebied van epilepsieonderzoek en onderzoek op het gebied van ziekte van Parkinson), Oogheelkunde en Farmacologie (op het gebied van hersenbloedingen na hartinfarct; gebruikmakend van een aldaar geïntroduceerd diermodel). Bij deze projecten ligt de nadruk op de betrokkenheid van het stikstof monoxide / cGMP systeem bij neuro-degeneratie. Het optreden of de gevolgen van dit systeem worden onderzocht aan humaan obductiemateriaal, in hersenen van proefdieren en in celkweken. 
Beschrijving vakgebied Cellulaire Neurowetenschappen

Bij het horen van mijn leeropdracht "Cellulaire Neurowetenschappen", zal niet iedereen een duidelijk beeld hebben van de inhoud ervan. Ik zal proberen u inzicht te geven in dit vakgebied en de richting waarin mijn onderzoeksinteresse gaat.

Reeds gedurende eeuwen zijn de hersenen en het zenuwstelsel het onderwerp van onderzoek geweest. Het is echter pas de laatste 25 jaren, dat er een ware explosie van activiteit op het gebied van Neurowetenschappen heeft plaats gevonden. Het brein onderhoudt via zintuigen, het zenuwstelsel en het hormoon systeem contact met de buitenwereld en met alle organen en weefsels van het organisme. Het brein neemt waar en reageert, het coördineert de activiteit van andere orgamen en lichaamsfuncties om het organisme te laten bestaan: eten, drinken, ademen, bewegen, voortplanten. Het legt ervaringen vast, interpreteert die, en gebruikt opgeslagen informatie op een later tijdstip.

Het brein is dan ook een orgaan met een hoge graad van specialisatie en organisatie, en is daardoor complex wat betreft zijn cellulaire opbouw. De hersenen van de mens bijwoorbeeld bestaan wit een 100 miljard newronen met onderling sterk uiteenlopende eigenschappen. Bijna ieder neuron is uniek door zijn eigen grootte, vorm, omgeving, plaats, verbindingen, neurotransmitters, receptoren en reacties op prikkels. Daarbij blijkt een hoge mate van selectiviteit.

Het werkgebied Cellulaire Neurowetenschappen benadert dit gebied met een nadruk op 1) basale biomedische aspecten, met name de neurochemie en verwante disciplines; 2) neurocognitieve- en gedragsaspecten en 3) klinische aspecten. Gedegen kennis van de fundamentele hersenprocessen is onontbeerlijk voor ons begrip van gedrags- en cognitieve processen bij de mens, en de 
ziektebeelden die met een stoomis daarin kunnen sameninangen. Het is van belang voor de positionering van het vakgebied van de cellulaire Neurowetenschappen om dit te plaatsen aan de biomedische kant wan een centrum waar humaan Hersenen \& Gedragsonderzoek aan het andere einde gesitueerd is.

Het vakgebied Cellulaire Neurowetenschappen

Het onderzoeksgebied Cellulaire Neurowetenschappen houdt zich bezig met het microscopisch onderzoek van de drie-dimensionale ordening van neuronale en niet-neuronale structuren in de hersenen. De afgelopen tien jaren zijn de onderzoeksmethoden binnen het vakgebied sterk uitgebreid. Zo heeft de toepassing van moleculair neuroanatomische technieken, zoals in-situ hybridisatie; immunocytochemie, al dan niet in combinatie met antero- en retrograde tracing technieken en receptor autoradiografie geleid tot een exacte beschrijving van de plaatsen waar de synthese, de transport routes, de eindigingsplaatsen en de afgifte en heropname van neurotransmitters plaatsvinden. Als al deze technieken worden gecombineerd en als het signaal wordt gekwantificeerd, is het mogelijk om een tamelijk volledig overzicht te verkrijgen van dynamische processen bimen de hersenen geïnitieerd vanuil verschillende fysiologische condities. Daardoor is het karakteriseren van neurotransmitters, receptoren en 'second messenger' systemen een belangrijke voorwaarde tot het verder ontwikkelen van dierexperimentele gedragsmodellen op het gebied van neurodegeneratieve aandoeningen.

De Cellulaire Neurowetenschappen biedt de unieke mogelijkheid om deze processen te vervolgen op cellulair niveau, zodat exacte veronderstellingen over 
de werkingswijzen wan nieuwe behandelingsmethoden, i.h. b. geneesmiddelen en hun toepassingen, bij bepaalde ziektebeelden kunnen ontstaan.

Gedragsveranderingen vastleggen in geheugen is gebaseerd op langdurige veranderingen in de zenuwcel. Het gedrag wordt geprogrammeerd in de hersenen. Onze hersenen zijn voortdurend aan veranderingen onderhevig. Ze zijn permanent bezig om informatie uit onze omgeving te verwerken en op te slaan. Deze veranderingen vinden plaats tijdens de hersenontwilkkeling en plasticiteit van het zenuwstelsel, tijdens leerprocessen en tevens tijdens verouderingsprocessen en dementie.

Naast de klassieke neuroanatomie van het traceren van neuronale verbindingen, tezamen met Golgi-kleuring en de elektronenmicroscoop, is de laatste jaren de chemische neuroanatomie tot ontwikkeling gekomen. Dankzij de chemische neuroanatomie is er in de afgelopen vifftien jaar zeer veel kennis vergaard omtrent het functioneren van moleculen in het zenuwstelsel. Bij de communicatie tussen neuronen spelen chemische stoffen, neurotransmitters, een belangrijke rol. De combinatie van tracing technieken met immunohistochemie geeft ons de gelegenheid specifieke vragen te stellen over de neurotransmitter-eigenschappen van bepaalde verbindingen. Het karakteriseren van neurotransmitters, receptoren en "second messenger" systemen is een belangrijke voorwaarde tot het verder ontwikkelen van dierexperimentele gedragsmodellen.

Ik wil nu nader ingaan op een tweetal deelaspecten om daarmee duidelijk de brugfunctio naar de vakgebieden Psychiatrie en (Neuro)psychologie te illustreren. Ik zal daarbij ingaan op twee neurotransmitter systemen, die sterk in de belangstelling staan: het serotonerge systeem en het systeen dat stikstof monoxide produceert. Het eerstgenoemde systeem is betrokken bij affectieve 
stoornissen, zoals depressie en het andere bij processen, die te maken hebben met oxidatieve stress en geheugen functies. Een relatie tussen een slecht functioneren van serotonerge neuronen en depressie wordt verondersteld door het feit dat tenminste bij een aantal patiënten die lijden aan deze affectieve stoomis de concentratie van 5-HT en zijn belangrijkste metaboliet (5-HIAA) in de liquor is afgenomen. Echter bij depressie zijn meerdere transmittersystemen betrokken gelokaliseerd in de hersenstam zoals ook de locus coeruleus en dus het noradrenerge systeem.

De verwevenheid tussen het serotonerge en het stikstofmonoxide systeem komt duidelijk naar voren als we een aantal functies vergelijken. Betreffende de centrale bloedvoorziening zorgt de serotonerge innervatie van kleine hersenbloedvaten voor samentrekking terwijl het stikstofmonoxide systeem juist contractie geeft. Daarom kan op een effectieve wijze de bloedvoorziening van de hersenen worden gereguleerd. Het serotonerge systeem is het eerste systeem dat sterk is aangedaan in de hersenen met als belangrijkste component de nucleus raphe dorsalis en de nucleus centralis superior. In deze hersenkernen komen beide neurotransmitters in hetzelfde celtype voor. Bij een diermodel voor de ziekte van Parkinson kunnen we zien dat een degeneratie van het serotonerge systeem leidt in het begin tot een toename van de activiteit van het dopaminerge systeem en daarna tot een retrograde degeneratie van het dopaminerge systeem richting substantia nigra. Waarom deze serotonerge cellen plotseling beginien te degenereren is tot nut toe niet duidelijk.

Speciale aandacht wordt gericht op de betrokkenheid van stikstof monoxide (NO) bij het ontstaan en beloop van neurodegeneratieve ziekten. NO is een reactief radicaal dat in combinatie met oxidatieve stress celdood kan veroorzaken. NO heeft een belangrijke boodschappersfunktie bij de cellulaire communicatie in het 
centrale zenuwstelsel. Activering van het enzym guanylaat cyclase door $\mathrm{NO}$ leidt tot verhoogde productie van de belangrijkste mediator van NO in de (gezonde) hersenen: GGMP. De betrokkenheid van NO bij de plasticiteit van het centrale zenuwstelsel tijdens de ontwikkeling, bij leer- en geheugen-processen, bij glutamaterge signaaltransduktie, bij regulatie van synthese en afgifte van dopamine, en bij serotonine-opslag en neurotransmissie, impliceert tevens dat cGMP bij al deze processen een rol speelt. Dit houdt in dat storingen in de regulatie van enerzijds NO-synthase of anderzijds de synthese en/of afbraak van cGMP grote gevolgen kan hebben voor het functioneren van de dopaminerge, serotonerge en glutamaterge neurotransmissie, en ten grondslag kunnen liggen aan zulke uiteenlopende ziektebeelden als depressie, ziekte van Parkinson en de ziekte van Alzheimer.

Ontwikkelingen binnen het vakgebied

De meest in het oog springende ontwikkeling binnen dit vakgebied is de overgang van een strikt monodisciplinaire aanpak naar een meer multidisciplinaire benaderingswijze: m.a.w. van klassieke neuroanatomie naar dynamische cellulaire Neurowetenschappen. Er bestaat een duidelijke kloof tussen enerzijds ons huidig begrip over de processen en organisatieniveaus op neuronaal niveau en anderzijds gedragsprocessen op dierexperimenteel en hunaan niveau. Een belangrijke ontwikkeling binnen het onderzoeksgebied is het onderzoek naar veranderingen tijdens veroudering en neurodegeneratie van receptor gemedicerde processen. Daarbij maken wij gebruik van activering/ stimulering van receptoren, 
waardoor microfarmacologische processen in gang worden gezet, die uiteindelijk tot gedragsveranderingen leiden.

Daarnaast is er een toenemende belangstelling voor verandering in genexpressie in neuronen bij neurodegeneratieve en neuropsychiatrische aandoeningen. Weefselkweek technieken bieden ons de mogelijkheid om op cellulair niveau factoren te onderzoeken die positieve en/of negatieve effecten hebben op de overleving van glia-cellen en meuronen.

Al deze studies vereisen computer-ondersteunende beeldbewerking, wararbij gedacht moet worden aan zowel 'Real Time Imaging' technieken, als kwantitatieve beeldbewerking van microscopische preparaten. Verder wil ik als belangrijke ontwikkeling de "genetic engineering" noemen. Door middel van recombinant DNA technieken zijn wij voomemens om transgene diermodellen te ontwikkelen die dienst kumnen doen om een aantal neurodegeneratieve ziektebeelden te bestuderen.

Bij alle studies geldt steeds als uitgangspunt: Het testen van een nieuwe verbinding begint met in vitro onderzoek op cellulair niveau, gevolgd door in-vivo psychoneuro-farmacologisch onderzoek; daarna komen de dierexperimentele gedragsstudies, het preklinisch humaan neuropsychologisch onderzoek en tenslotte de klinische toepassingen. Bij het proefdieronderzoek zullen wij ernaar streven, gebruik te maken van de belangrijke nieuwe ontwikkeling om met geavanceerde Kernspinresonantie (MRI)-technieken te kijken naar vorm- en functieveranderingen in de hersenen.

Recent zijn nieuwe technieken ontwikkeld voor het toepassen van functionele neuroanatomie op het niveau van 'second' en 'third messenger' systemen. Daarbij wordt het mogelijk om de interaches van neurotransmittersystemen (i.h.b. het serotonerge, dopaminerge en stikstof monoxide - systeem) in relatie tot leer-en 
geheugen processen te bestuderen. Hierbij wordt vooral gefocust op onderzoek in de basale ganglia en het limbisch systeem van de rat. De veranderingen worden beschreven aan de hand van morfologische, neurochemische, neurofarmacologische en gedragsparameters.

Bestudering van Neurodegeneratie en Plasticiteit

Veroudering van o.a. monoaminerge systemen wordt onderzocht met immunocytochemische technieken m.b.v. antilichamen tegen dopamine, noradrenaline en serotonine. Veranderingen in de gen-expressie in deze neuronen worden gekwantificeerd met in-situ hybridisatie metingen, waarbij mRNA probes van neurotransmitter-synthetiserende enzymen, in combinatie met beeldbewerking, worden gebruikt. Veranderingen van cellen die een dopaminerge of serotonerge afferentie verkrijgen, zoals cholinerge en peptiderge neuronen, kunnen worden bestudeerd op basis van hun morfologie en activiteit.

Stikstof monoxide (NO) is een reactief radicaal dat in de bloedvaten van het levend organisme werkzaam is als vaatverwijder; als een toxisch molecule speelt het een rol bij ontstekingsprocessen, en kan fungeren als een neurotransmitter of neuromodulator in het centraal zenuwstelsel (CZS).

Een van de belangrijkste effecten van $\mathrm{NO}$ is de activering van de oplosbare vorm van het enzym guanylaat cyclase, hetgeen resulteert in een verhoogde cGMP productie. NO gemedieerde cGMP productie komt algemeen voor in het centrale zenuwstelsel. Toch is er weinig bekend omtrent de regulatie en de betekenis wan dit signaaltransduktiesysteem. De functie van CGMP is afhankelijk van het repertoire aan target structuren voor cGMP dat in een bepaalde cel aanwezig kan 
zijn. Er zijn aanwijzingen voor een grote diversiteit voor wat betreft lokalisatie en biochemische specificiteit van deze cGMP-targets. Dit biedt in principe een heel scala van mogelijkheden tot het ontwikkelen van selectieve farmaca. Echter, over de cellulaire lokalisatie van deze macromoleculen en de interacties met andere "second messenger" systemen is nog weinig bekend, ondat de gereedschappen voor een deel ontbreken om de activiteit van deze structuren op cellulair niveau, ingebed in hun oorspronkelijke omgevingstrukturen, te bestuderen.

Met behulp van moleculair biologische technieken (b.v. clonering cGMPbindingsplaatsen) en middels het ontwikkelen van antilichamen tegen specifieke (delen) van enzymen betrokken bij dit signaaltransduktie systeem, kan de rol van NO en cGMP in het gezonde en door ziekteprocessen aangedane centrale zenuwstelsel duidelijk gemaakt worden.

Omdat het NO-cGMP signaaltransduktiesysteem overal in het centrale zenuwstelsel voorkomt, is voor de bestudering van de centrale (hypothetische) rol van cGMP bij cel- en weefselhomeostase, kennis ontrent de regulatie van dit signaaltransduktiesysteem in het gezonde en zieke centrale zenuwstelsel van groot belang. Dit heeft geleid tot een voor ons centrale vraagstelling: Wat is de rol en functie van NO bij plasticiteit en neurodegeneratie in het centrale zenuwstelsel en welke is de relatie tussen NO, oxidatieve siress en geprogrammeerde celdood (apoptosis)?

De laatste jaren worden een groot aantal pogingen ondernomen om met behulp van foetale hersenceltransplantaties functionele veranderingen die ontstaan door het uitvallen van een of meerdere transmitter-specifieke systemen in de hersenen, te compenseren. Deze cellen kunnen functionele synaptische contacten tussen transplantaat en het gastheerbrein vormen. Weliswaar werd nog tot voor kort de 
stelling geponeerd dat de hersenen een geprivilegieerde inimunologische plaats zouden zijn waarbij gesn afstotingsreakties zouden kunnen woorkomen, echter de laatste tijd komen er steeds meer resultaten, ook uit ons eigen laboratorium, dat door het implanteren van foetale thersencellen de bloed-hersen barrière wordt beschadigd. Dit heeft tot gevolg dat een grote infiltratie van macrofagen in het gastheer brein kan platsvinden. Deze infiltratie van macrofagen zouden én van de factoren kunnen zijn die in hoge mate voorkomt bijj de ziekte van Alzheimer. Het transplantatie in principe veelbelovend is door ons niet woortgezet, omdat wij ons primair willen richten op onderzoek naar het ontstaan van het ziektebeeld en niet een substitutietherapie in een nog steeds ziek brein willen onderzoeken.

Onderzoeksplannen in de Cellulaire Neurowetenschappen

De komende jaren zullen een aantal nieuwe initiatieven worden gestart en verder worden uitgebouwd. Het onderzoek zal zich concentreren zich op het detecteren, valideren en gedragsmatig incorporeren van diermodellen voor neurodegeneratieve aandoeningen, waarbij vagen vanuit de kliniek centraal staan.

Een tweede belangrijk aandachtspunt is de studie naar het functioneren van de interactie tussen transmittersystemen in voorhersengebieden, zoals het striatum en de hippocampus. Hierbij ligt de nadruk op de bestudering van het stikstof monoxide/ cGMP systeem en het serotonerge systeem t.a.v. neurodegeneratie, ontwikkelingsneurobiologische vraagstellingen en regeneratie van het centrale en perifere zentwwstelsel. Veranderingen worden beschreven aan de hand van morfologische, moleculair neurobiologische, neurochemische, -farmacologische 
en gedragsparameters. Aktiviteitsveranderingen in de o.a. degenererende neuronen worden gekwantificeerd m.b.v. in-situ hybridisatie, gebruik makend van mRNA probes van synthetiserende enzymen, in combinatie met beeldbewerking.

Met het oog op de toepassing van de verworven kennis bij de thenapie zal aandacht worden besteed aan de vraag:

Welk effect heeft een chronische behandeling met farmaca op de degeneratie en regeneratie? Bij het onderzoeken van gedragsmatig funktieverlies of -herstel wordt gelet op bekende cognitieve- en affectieve-geassocieerde gedragsparameters. Op basis van morfologische bevindingen wordt aandacht besteed aan: ruimtelijke oriëntatie, al dan niet in een sociale context (hippocampus functie) en aan de "fijnregeling" van gedrag (neostriatum).

Met de hier geschetste combinatie van fundamentele en toegepaste aspecten, met als uiteindelijk doel, de vroege diagnostiek en de individuele therapiemogelijkheden te verbeteren, kan mogelijkerwijs de kloof tussen onze kennis van cellen en moleculen enerzijds en het begrijpen van neurodegeneratieve verschijnselen anderzijds, meehelpen te verkleinen.

Daarbij zal naar alle waarschijnlijkheid het neuron als bruggenbouwer tussen de diverse onderzoeksdisciplines de sleutel tot menig antwoord geven. 
Onderwijs in de Cellulaire Neurowetenschappen

Het is van belang hier stil te staan bij de nadruk, die in het Maastrichtse curriculum wordt gelegd op de afstemming tussen het onderwijs en de eerstelijns gezondheidszorg. De relevantie hiervan wordt benadrukt door het feit, dat met name de eerstelin in aarraking komt met problemen op het gebied van neuropsychologische/ psychiatrische aandoeningen. Dit leidt tot het besef, dat de student niet alleen kennis moet hebben van de meest frequent voorkomende psychopathologische beelden, maar ook van vroege en veelal minder ernstige verschijningsvormen en met de risicofactoren, die met het ontstaan van deze stoornissen in verband staan.

Dit alles impliceert, dat in het basiscurriculum naast de verschillende psychische functies, ook de ontwikkelingspsychologische en de neurobiologische oftewel de cellulaire neuroweten-schappelijke aspecten aan de orde moeten zijn geweest. Ongeacht het medisch specialisme dat later zal worden beoefend, dient de basisarts zich deze basale kemnis eigen te maken.

Momenteel worden onderwijsbijdragen gegeven in een aantal blokken binnen het geneeskunde curriculum. Voorts worden bijdragen gelleverd aan opleidingen binnen de Faculteit der Gezondheidswetenschappen en de Faculteit der Algemene Wetenschappen/Psychologie. 
Tweede fase onderwijs:

Naast de reguliere onderwijsverplichtingen ten aanzien van college- en praktijkonderwijs (practica), zijn lopende onderwijsactiviteiten van de Cellulaire Neurowetenschappen tevens gericht op het opzetten en verzorgen van weede fase onderwijs. Binnen dit onderwijs staan affectieve stoomissen, zoals depressie en cognitieve stoomissen (zoals de ziekte van Alzheimer) en motorische stoomissen (zoals de ziekte van Parkinson) central. Getracht wordt informatie te verschaffen vanuit vier verschillende disciplines waardoor de AlO/Postdoc aan de hand van diermodellen van deze ziektebeelden inzicht krijgt in de pathofysiologie en mogelijke therapentische aspecten. Up-to-date en all-round AIO onderwijs is van groot belang voor de $\mathrm{AlO}$ zelf: de $\mathrm{AIO}$, gepromoveerd vanuit de $\mathrm{UM}_{\text {, zal }}$ daardoor een brede oriëntatie met voldoende diepgang hebben waardoor hij goed is woorbereid op verschillende mogelijkheden voor een camrière binnen een universiteit of in de industrie.

Tweede fase onderwijs vindt plaats met de drie K.N.A.W.-erkende onderzoeksscholen: 'Onderzoeksschool Neurowetenschappen Amsterdam', 'Pathofysiologie van het Zenuwstelsel' (Utrecht, Wageningen en Nijmegen) en de Groningse 'Onderzoeksschool BCN'. Met al deze scholen zijn inmiddels formele samenwerkingsverbanden besproken. Daarbij wordt aan AlO's de mogelijkheid geboden om door middel van een gesloten beurzenprincipe deel te kunnen nemen aan reguliere cursussen gegeven in een van de drie onderzoeksscholen en thet Maastrichtse Instituut Hersenen \& Gedrag. 
Ten aanzien van speciaal AlO-onderwijs op euregionaal niveau, worden nieuwe AlO onderwijsactiviteiten opgezet. De organisatie daarvan wordt verricht vanuit de Euregionale Onderzoeksschool in de Neurowetenschappen (EURON). Deze school wordt momenteel vormgegeven met als zwaartepunten Maastricht (als penvoerder) Aken en Luik en daaraan toegevoegd Leuven en Brussel.

Internationale samenwerking is reeds in volle gang met vier Japanse universiteiten middels een aantal beurzen verkregen via het Japanese Society for Promoting Science / Nuffic programma, dat de uitwisseling van studenten, AlO's, postdocs en senior wetenschappers bevordert. De vier japanse universiteiten zijn 'Osaka University', 'Prefectural University of Kyoto', 'Tohoku University" te Sendai en "Ehime University" te Matsuyama. Daarnaast is een officieel samenwerkingsverband gestart met het Montreal Neurological Instituut, Camada en het 'Neuroscience Institute' van de Dalhousie Universiteit te Halifax, Canada. Binnen al deze vormen van samenwerking wordt gestreefd naar een directe relatie tussen klinisch en preklinisch onderzoek.

Resumerend wil ik vaststellen, dat Cellulaire Neurowetenschappen een zich dynamisch ontwikkelend vak is, waarbij het basale neurowetenschappelijke onderzoek van de hersenen wordt geûnspireerd door vragen vanuit de Psychatrie, Neuropsychologie en Neurologie. Het is een multidisciplinair onderzoeksgebied, waarin bij de veelzijdige bestudering van het neuron als centraal thema bruggen worden geslagen tussen de klassieke neuroanatomie, de neurochemie, neurofarmacologie en het dierexperimentele neuropsychologische /neuropsychiatrisch gedragsonderzoek. Het beoogt de mechanismen van neurotransmissie te doorgronden om wan daaruit de fysiologische betekenis van 
dierexperimentele gedragsstudies en uiteindelijk klinische stoomissen op het gebied van neurodegeneratieve aandoeningen en neuropsychiatrische condities te ontrafelen. 
Dankwoord

Ik zou deze rede graag willen besluten met een aantal woorden wan dank en waldering.

Mijnheer de Rector Magnificus, leden van het College van Bestuur, het Bestuur van de Faculteit der Geneeskunde en leden van het bestuur van het linstituut Hersenen en Gedrag. Ik will u bedlanken voor het vertrouwen dat $u$ in mij stelt blijkens mijn benoeming tot profileringshoogleraar. Ik wil de Stichting Wetenschapsbeofening Liniversiteit Maastricht voor hun bijdrage daarin bedanken.

Hooggeleerde Prof. Nieuwenhuis en Dr. Verhofstad,

Het is een ruime tijd geleden sinds mijn promotie op 1 april 1982. Ik wilde U, als mijn promotor en als dagelijkse begeleider bedanken woor de streng calvinistische wijze waarop $U$ mij met veelal relativerende adviezen hebt begeleid. Hetgeen heeft geleid tot mijn cum laude promotie.

Hooggeleerde Prof. Smelik, Prof. Mulder, Prof. Stoof en Prof. Tilders, beste Pieter, Arie, Hans en Fred,

Ik verkeerde in 1982 in de gelukkige omstandigheid dat ik weliswaar nog moest promoveren, maar aan de Katholieke Universiteit te Nijmegen reeds voortijdig ontslag had genomen zodat ik Amsterdam aan de Vrije Universiteit kon starten. Dus eigenlijk is het promotieproject niet zoals gebrukelijk uitgelopen, maar werd drie maanden voor het einde van het project ontslag genomen. Pieter, ik heb tot aan je emeritaat onder jouw leiding mogen werken binnen de vakgroep 
Farmacologie. Ik heb veel aan je te danken, maar wat ik het meest in je heb gewaardeerd is je actieve bijdrage om mijn discipline een eigen positie te geven tussen de farmacologie en de endocrinologie. Aan jullie vieren heb ik twee dingen bijzonder gewaardeerd: op de eerste plaats de vrijheid die jullie mij hebben gegeven om nieuwe wegen te bewandelen en contacten te leggen. Daarnaast heb $\mathrm{ik}$, via allerlei commissies in Amsterdam, ervaring in management-structuren opgedaan binnen het bestuur van de door de K.N.A.W. erkende onderzoeksschool "Neurowetenschappen Amsterdam" en ben ook daardoor verder geëvalueerd als neurowetenschapper.

Hooggeleerde Prof. van Praag, beste Heman, Hooggeleerde prof. Troost, beste Jaap,

Met $U$ als respectievelijk oud voorzitter en ad-interim voorzitter van de vakgroep Psychiatrie en Neuropsychologie, heb ik de afgelopen 4 jaren met veel plezier en inzet mogen samenwerken. Mijn komst naar Maastricht heeft mij tevens weer in de gelegenheid gesteld mijn oude liefde, het onderzoek naar de functie van serotonine, opnieuw op te pakken. lets dat binnen onze huidige vakgroep binnen alle geledingen een vruchtbare bodem heeft gevonden.

Hooggeleerde Prof. Jolles, beste Jelle

Het is nu bijna vijf jaar geleden dat ik vanuit Amsterdam naar Maastricht kwam om eerst als universitair hoofddocent en sedert vorig jaar als collega binnen hetzelfde Instituut en Vakgroep met jou samen te werken. Ons eerste contact was echter reeds via Prof. Greep met de Rijksuniversiteit Limburg in 1984. Ik bewonder je grote inzet en het grote aantal verscheiden neuropsychologische projecten die onder jouw hoede plaatsvinden. Ik hoop dat ons instituut binnenkort 
in dusdanig rustig vaarwater terecht komt, dat we een brug kunnen slatan middels nieuwe projecten tussen Basale Neurowetenschappen en Neuropsychologie.

Directie en bestutur van het Instituut Hersenen en Gedrag Kenmerkend en verheugend voor het Institunt is, dat wij geleidelijk aan dezelfde wetersechappelijke taal zijn gaan spreken. Ik dank $U$ voor het vertrouwen dat $U$ in mij stelt middels minn bestuursfunctie als programmaleider.

Medewerkers van sectie Basale Neurowetenschappen:

De voortgang van ons onderzoek wordt in sterke mate bepaald door jullie werk. Jullie inzet en vooral loyaliteit verlichten mijn dagen. Ik ben jullie daar allemaal zonder uitzondering, bijzonder dankbaar voor, maar vooral Jan de Vente die mij al sinds 1983 terzijde staat. Voor de andere medewerkers moet ik mij beperken. Ik noem slechts zeven namen in wie ik allen bedank: Arjan Blokland, Wiel Honig, Marjan Markerink, Jos Prickaerts, Hellen Steinbusch, Lilian Swaen en Dick Terwel.

Members of EURON, the Euregional Graduate School of Neuroscience, in particular Prof. Korr from the Rheinisch Westfalische Technische Hochschule Aachen, Prof. Vandesande from Catholic University of Letren and Prof. Balthazart from the University of Liege as representatives from the three participating Universities. I thank you for atrending my inaugural lecture and I hope, as Chairman of the Board of EURON, that we will have the possibility to expand, or should 1 say, collateralize and build a highwaybridge for our educational and scientific connections. 
Mijn ouders:

Ik wil mijn ouders bedanken voor het feit, dat zij mij de gelegenheid hebben gegeven om een goede opleiding te volgen. Ik heb deze kans wolledig benut:

Beste Gonny, Laura en Karlijn

Op deze plaats wordt altijd gememoreerd dat de jonge hoogleraan hier niet had gestaan zonder de bescheiden steun op de achtergrond van de partner, die het gezin draaiende wist te houden. Ik wil jou daarom bedanken voor het uitgesproken vertrouwen dat je altijd in mij hebt gehad, voor het geduld, rusi en steun die je me geeft. Voor al die voorbije jaren dat ik best moe thuis kwam, of ook zoals gewoonlijk 's avonds nog correspondentie van mijn tijdschrift moest bijwerken. Laura en Karlijn vroegen mij vorig jaar juli, toen het definitieve bericht binnenkwam van mijn benoeming:"Is dit nu een eindpunt, wordt het nu thuis eindelijk eens rustig?" Ik zal jullie helaas moeten teleurstellen. Ik zie dit niet als een eindpunt, maar veeleer als een nienwe uitdaging voor een toekomst.

Dames en Heren studenten,

Niet voor niets worden volgens traditie de laatste woorden van een inaugurele rede gericht tot $\mathrm{U}$. Mijn gehele betoog was er op gericht om u duidelijk te maken dat Hersenen \& Gedrag en Cellulaire Neurowetenschappen in het bijzonder een uitdagend en nog een steeds wrijwel braakliggend terrein is. Niet alleen binnen de Faculteit der Geneeskunde, maar ook binnen de Faculteiten Gezondheidswetenschappen en Psychologie ben ik vanaf het eerste tot en met het derde jaar via blokcoördinatorschap, practicumcoördinator, werkcolleges, practica, tutorschappen, inhaalcolleges, snuffelstages, wetenschapsstages, buitenlandse keuzestages, studentassistentschappen in contact met $U$ gekomen. 
De officiële norm van 0,05 fte onderwijsformatie die ik jaarlijks moet vervullen valt hierbij absoluut in het niet. Maar ieder jaar weer, als ik de vorderingen zie die studenten in een half jaar maken en ik een stuk enthousiasme voor hef wetenschappelijke werk kan overdragen, weet ik dat het de tijdsinvestering waard is geweest. IK hoop nog een groot aantal jaren steeds weer met $U$ samen te werken, want $U$ bent de onderzoeker van de toekomst.

Itk heb gezegd.

5 maart 1999 